\title{
Pertanggungjawaban Pidana Pengambilan Jenasah Covid-19 Secara Paksa Berdasarkan Aturan Tindak Pidana Umum dan Tindak Pidana Khusus
}

\author{
Jacob Hattu ${ }^{1 *}$ \\ ${ }^{1}$ Fakultas Hukum Universitas Pattimura \\ hattuyopie@gmail.com ${ }^{1}$ \\ * Corespondence Author
}

\begin{abstract}
Abstrak
Pengambilan jenasah virus corona secara paksa merupakan perbuatan melawan hukum baik aturan pidana umum maupun atauran pidana khusus. Dalam perbuatan pengambilan jenasah virus corona tentu melibatkan lebih dari satu orang. Penyertaan diatur dalam Kitab Undang-Undang Hukum Pidana yang berarti bahwa ada dua orang atau lebih yang melakukan suatu tindak pidana atau dengan perkataan ada dua orang atau lebih mengambil bagian untuk mewujudkan suatu tindak pidana. Oleh karena itu penyertaan sebagai dasar memperluas dapat dipidananya orang yang tersangkut dalam terwujudnya delik. Pertanggungjawaban pidana mengandung makna bahwa setiap orang yang melakukan tindak pidana atau melawan hukum, sebagaimana dirumuskan dalam undang-undang, maka orang tersebut patut mempertanggungjawabkan perbuatan sesuai dengan kesalahannya. Orang yang melakukan perbuatan pidana akan mempertanggungjawabkan perbuatan tersebut dengan pidana apabila ia mempunyai kesalahan, seseorang mempunyai kesalahan apabila pada waktu melakukan perbuatan dilihat dari segi masyarakat menunjukan pandangan normatif mengenai kesalahan yang telah dilakukan orang tersebut.
\end{abstract}

Kata Kunci : Pertanggunjawaban pidana, Covid-19, Perbuatan.

Naskah dikirim: 13 Juli 2020|Direvisi : 10 Agustus 2020|Diterbitkan: 22 Agustus 2020 


\begin{abstract}
Forcibly taking the corpse of the corona virus is an act against the law, both general criminal rules and special criminal regulations. In the act of taking the corpse of the corona virus, it certainly involves more than one person. Inclusion is regulated in the Criminal Code, which means that there are two or more people who have committed a criminal act or that is, two or more people take part in realizing a criminal act. Therefore participation as a basis for widening the conviction of the person involved in the realization of the offense. Criminal liability means that every person who commits a criminal act or violates the law, as defined in the law, then that person should be held accountable for the act according to his mistake. an error if at the time of committing an action seen from the perspective of society it shows a normative view of the mistakes that person has committed.
\end{abstract}

\title{
Keywords: Criminal liability, Covid-19, Action
}

\section{Pendahuluan}

Covid-19 menyebar ke seluruh dunia silih berganti dengan cara penularan yang disebut kasus impor dari luar wilayah asal atau transmisi lokal antarpenduduk. Sejauh ini, berbagai peristiwa yang pertama kali terjadi berkaitan dengan Covid-19 agaknya belum memberikan gambaran utuh tentang virus ini. Analisis para ahli menduga bahwa Covid-19 lebih kuat bertahan hidup di daerah bersuhu rendah dan kering walaupun virus ini juga mewabah di negara-negara dengan kondisi suhu dan kelembaban udara yang sebaliknya. Virus ini juga lebih rentan menyebabkan kematian pada penduduk usia lanjut. Namun, ada juga penduduk di kelompok usia ini yang berhasil sembuh dan seorang bayi juga meninggal karena Covid-19.

Untuk pertama kalinya, China melaporkan adanya penyakit baru ini pada tanggal 31 Desember 2019. Pada pengujung tahun 2019 itu, kantor Organisasi Kesehatan Dunia (WHO) di China mendapatkan pemberitahuan tentang adanya sejenis pneumonia yang penyebabnya tidak diketahui. Infeksi pernapasan akut yang menyerang paru-paru itu 
terdeteksi di kota Wuhan, Provinsi Hubei, China. Menurut pihak berwenang, beberapa pasien adalah pedagang yang beroperasi di Pasar Ikan Huanan. ${ }^{1}$

Pada tanggal 2 Maret 2020, untuk pertama kalinya pemerintah Indonesia mengumumkan dua kasus pasien positif Covid-19. Namun, Masuknya virus tersebut sangat mungkin terjadi melalui pintu-pintu gerbang di beberapa wilayah Indonesia. Sejak Januari saat virus corona jenis baru ini diumumkan dapat menular antar manusia, dan sudah menjajah di berbagai negara lain selain Wuhan di China. Pemerintah Indonesia tidak lantas langsung menutup akses penerbangan langsung dari dan ke Wuhan, yang ada di sekitar enam bandara. Antara lain Batam, Jakarta, Denpasar, Manado Makassar. ${ }^{2}$

Virus corona merupakan keluarga virus yang menaungi SARS-CoV-2 yang terjadi saat ini, SARS-CoV pada 2002, dan MERS-CoV pada 2012. Kata corona sendiri berasal dari bahasa Latin yang berarti mahkota. Bentuk virus corona menyerupai mahkota. Sedang penyakit yang disebabkan SARS-CoV-2 disebut Covid-19, akronim dari coronavirus disease 19. ciri-ciri virus corona hampir mirip dengan gejala flu, di antaranya:

Demam tinggi lebih dari 38 derajat Celsius

Batuk kering

Lemas

Sakit tenggorokan

Sesak atau kesulitan bernapas

Sakit kepala.

Virus corona bersifat zoonotik. Ini berarti, virus pertama kali berkembang di hewan sebelum akhirnya menyerang manusia. Ketika sudah menginfeksi manusia, penyebaran virus corona bisa melalui droplet pernapasan.Kemudian, virus akan menginfeksi manusia ketika tangan yang terkontaminasi oleh virus menyentuh wajah, seperti mulut, hidung, dan mata.

17 Juli 2020

${ }^{1}$ https://bebas.kompas.id/baca/riset/2020/04/18/rangkaian-peristiwa-pertama-covid-19/ diakses

${ }^{2}$ https://www.kompas.com/sains/read/2020/05/11/130600623/diumumkan-awal-maret-ahli-virus-corona-masuk-indonesia-dari-januari diakses 17 Juli 2020

DOI : https://doi.org/10.30598/belovol6issue1page11-31 
Percikan batuk atau bersin dari orang yang terinfeksi virus corona akan menempel di permukaan benda atau kulit manusia. Sehingga, virus akan berpindah ketika manusia menyentuh benda atau melakukan kontak fisik dengan manusia lainnya. Dengan demikian ada risiko terinfeksi virus ketika seseoarang berdekatan atau melakukan kontak fisik dengan orang terinfeksi virus corona. $^{3}$ Bagi pasien yang telah wafat akibat Covid-19 tentu dilakukan pengangan sesuai dengan protokol pengurusan jenasah Covid-19, namun yang terjadi banyak peristiwa pengambilan paksa jenazah pasien Covid-19 oleh keluarganya marak terjadi di berbagai daerah di Indonesia. Menghadapi situasi yang demikian, pihak kepolisian bertindak tegas dengan cara melakukan proses hukum kepada sejumlah orang yang diduga terlibat dalam pengambilan paksa jenazah pasien Covid-19. Tindakan kepolisian tersebut di satu sisi bertujuan menegakkan hukum guna mencegah semakin masifnya pengambilan paksa jenazah pasien Covid-19 oleh keluarga pasien.

Dalam pelbagai literatur, tujuan pidana secara garis besar diarahkan untuk memberantas kejahatan secara represif sebagai ciri khas teori absolut dan mencegah terjadinya kejahatan secara preventif sebagai teori relatif. Di luar dua teori tujuan pidana itu, masih ada teori gabungan yang menitikberatkan pada pembalasan dan perlindungan masyarakat secara bersamaan.Menghadapi situasi yang demikian, pihak kepolisian bertindak tegas dengan cara melakukan proses hukum kepada sejumlah orang yang diduga terlibat dalam pengambilan paksa jenazah pasien Covid-19. Tindakan kepolisian tersebut di satu sisi bertujuan menegakkan hukum guna mencegah semakin masifnya pengambilan paksa jenazah pasien Covid-19 oleh keluarga pasien.

Penindakan terhadap pelaku pengambilan jenasah Covid-19 aparat pengak hukum menjerat para tersangka pun pasal berlapis yaitu pasal 214 KUHP jo, Pasal 335 KUHP jo, Pasal 336 KUHP jo,Pasal 93 KUHP serta UU Nomor 6/2018, tentang Karangtinaan kesehatan hal ini dapat menimbulkan pertanyaan mengapa tidak dipakai Undangundang Wabah Penyakit Menular, karena Covid-19 merupakan penyakit menular, sedangkan undang-undang No 6 tahun 2018 secara implisit hanya mengatur mengenai

${ }^{3}$ https://www.kompas.com/sains/read/2020/05/11/130600623/diumumkan-awal-maret-ahli-virus-corona-masuk-indonesia-dari-januari. diakses 17 Juli 2020 
wabah penyikit. Tujuan penulisan ini untuk menemukan bentuk pertanggunjawaban pidana dalam pengambilan jenasah covid-19 cera paksa berdasarkan Aturan tindak pidana umum dan aturan tindak pidana Khusus. Penulisan ini merupakan penulisan baru yang belum perna diangkat dalam tulisan yang membahas tentang pertangungjawaban pidana. Terakhir tulisan tentang pertangungjawaban pidana berbicara tentang Pertanggungjawaban pidana dalam hukum pidana mengenal dua jenis kesalahan, yaitu kesalahan normatif dan kesalahan psikologis. Berkaitan dengan hal ini, Kitab UndangUndang Hukum Pidana (KUHP) di dalam Pasal 44 mengatur mengenai bentuk negatif dari kemampuan bertanggungjawab seseorang. Dalam perkembangan ilmu pengetahuan saat ini, banyak unsur yang dapat menjadi aspek pertimbangan di dalam menentukan kemampuan bertanggungjawab seseorang. ${ }^{4}$ Menjaga agar pelaku dan calon pelaku suatu tindak pidana mendapat efek jera agar tidak ada residivis dalam tindak pidana yang sama maka permintaan pertangungjawaban pidana harus tetap dimintakan. ${ }^{5}$

\section{Pembahasan}

\section{a.Pengertian dan Jenis-Jenis Tindak Pidana}

Membahas masalah tindak pidana maka terlebih dahulu kita mengerti apa pidanaitu, hukum pidana dan segala pengaturanya diatur dalam Kitab UndangundangHukum Pidana serta Kitab Undang-undang hukum Acara Pidana.Menurut Roslan Saleh, Pidana adalah reaksi atas delik dan ini berwujud suatunestapa yang dengan sengaja ditimpakan negara pada pembuat delik itu.Dikatakan Simons bahwa strafbaar feit itu adalah "kelakuan (handeling) yangdiancam dengan pidana, yang diancam dengan pidana, yang bersifat melawanhukum, yang berhubungan dengan kesalahan, dan yang dilakukan oleh orang yangmampu bertanggung jawab. ${ }^{6}$

4 Paramita Sari, A. (2017). Pertanggungjawaban Pidana dan Pemidanaan Terhadap Pelaku Pedofilia Dalam Hukum Pidana Indonesia. Jurnal Magister Hukum Udayana (Udayana Master Law Journal), 6(1), 23 - 36. doi:10.24843/JMHU.2017.v06.i01.p03

${ }^{5}$ Marthsian Y Anakotta, (2020). Kebijakan Sistem Penegakan Hukum Terhadap Penanggulangan Tindak Pidana Terorisme Melalui Pendekatan Integral, Jurnal Belo 5(1), 46-66

${ }^{6}$ Roeslan Saleh, "Perbuatan Pidana dan Pertanggungjawaban Pidana, Dua Pengertian Dasar dalam Hukum Pidana", Centra, Jakarta, 2011. hal 61 
Menurut Sudarto, pembentuk undang-undang sekarang sudah agak tetap dalam pemakaianistilah yakni tindak pidana sebagai pengganti strafbaarfeit, hal ini ditunjukkan pada beberapaperaturan perundang-undangan antara lain: UndangUndang Darurat No. 7 Tahun 1995 tentangPengusutan, Penuntutan, Peradilan Tindak Pidana Ekonomi. ${ }^{7}$ Selanjutnya Menurut Moeljatno, perbuatan pidana adalah perbuatan yang dilarang oleh suatu aturanhukum larangan mana disertai ancaman (sanksi) yang berupa pidana. Moeljatno berpendapatbahwa, "Perbuatan pidana adalah perbuatan yang oleh suatu aturan hukum dilarang dan diancamdengan pidana, asal saja dalam pidana itu diingat bahwa larangan tersebut ditujukan padaperbuatan yaitu suatu keadaan atau kejadian yang ditimbulkan oleh kelalaian orang, sedangkanancaman pidananya ditujukan kepada orang yang menimbulkan kejadian tersebut"ancaman pidananya ditujukan kepada orang yang menimbulkan kejadian tersebut". ${ }^{8}$

Sedangkan perumusan strafbaarfeit, menurut Van Hammel, adalah sebagai berikut :

"Strafbaarfeit" adalah kelakuan orang yang dirumuskan dalam undangundang, bersifat melawanhukum yang patut dipidana dan dilakukan dengan kesalahan. Maka sifat-sifat yang ada dalamsetiap tindak pidana adalah sifat melanggar hukum(wederrectelijkheid, onrechtmatigheid).

Berkaitan dengan Unsur-Unsur Tindak Pidana maka enurut Lamintang, tindak pidana dalam KUHP pada umumnya dapat dijabarkan unsur unsurnya menjadi 2 (dua) macam, yaitu unsur-unsur subjektif dan objektif. Unsur-unsur subjektif adalah unsur-unsur yang melekat pada diri si pelak atau yang berhubungan pada diri si pelakudan termasuk kedalamnya yaitu segala sesuatu yang terkandung di dalam hatinya. Sedangkanyang dimaksud unsur objektif itu

\footnotetext{
${ }^{7}$ Adami Chazawi, Pelajaran Hukum Pidana II, Raja Grafindo Persada, Jakarta, 2017. hal. 67.

${ }^{8}$ C.S.T. Kansil dan Christine S.T Kansil, Pokok-Pokok Hukum Pidana, Pradnya Paramita,Jakarta, 2014, hal. 54 
adalah unsur-unsur yang ada hubungannya dengan keadaankeadaan mana tindakan dari si pembuat itu harus dilakukan. ${ }^{9}$

Unsur subjektif dari suatu tindak pidana adalah: ${ }^{10}$

1. Kesengajaan atau ketidaksengajaan (culpa dan dolus).

2. Maksud dan voornemen pada suatu percobaan atau poging seperti yang dimaksud dalam Pasal 53 ayat 1 KUHP.

3. Macam-macam maksud atau oogmerk seperti yang terdapat misalnya di dalam kejahatankejahatan pencurian, penipuan, pemerasan, pemalsuan, dan lain-lain.

4. Merencanakan terlebih dahulu atau voorbedachteraad seperti misalnya dalam kejahatan pembunuhan menurut Pasal 340 KUHP.

5. Perasaan takut atau vress seperti yang antara lain terdapat didalam rumusan tindak pidana pembuangan bayi menurut Pasal 308 KUHP.

Sedangkan unsur objektif dari suatu tindak pidana adalah:

1. Sifat melanggar hukum.

2. Kualitas si pelaku.

3. Kausalitas, yakni hubungan antara suatu tindakan sebagai penyebab dengan suatu kenyataan sebagai akibat.

Lebih lanjut menurut Moeljatno bahwa untuk adanya perbuatan pidana harus ada unsur-unsur :

1. Perbuatan oleh manusia.

2. Memenuhi rumusan undang-undang (syarat formil)

3. Bersifat melawan hukum (syarat materiil)-unsur:

Syarat formil itu harus ada karena keberadaan asas Legalitas yang tersimpan dalam Pasal 1 ayat (1) KUHP. Syarat materiil pun harus ada pula, karena perbuatan itu harus pula betul-betul dirasakan oleh masyarakat sebagai perbuatan yang tidak boleh atau tidak patut dilakukan, oleh karena itu bertentangan dengan

${ }^{9}$ P.A.F. Lamintang, Dasar-dasar Hukum Pidana Indonesia, Sinar Baru,Bandung, 2014, hal 184

${ }^{10}$ Ibid

DOI : https://doi.org/10.30598/belovol6issue1page11-31 
atau menghambat tercapainya tata dalam pergaulan masyarakat yang dicitacitakan oleh masyarakat itu. ${ }^{11}$

\section{b. Jenis-Jenis Tindak Pidana}

Tindak pidana umum ini ialah suatu perbuatan pidana yang pengaturannya terdapat dalam Kitab Undang-Undang Hukum Pidana yang terdiri dari :

a. Tindak Pidana Umum

Tindak pidana umum ini ialah suatu perbuatan pidana yang pengaturannya terdapat dalam Kitab Undang-Undang Hukum Pidana.

b. Kejahatan

Kejahatan adalah perbuatan yang melanggar dan bertentangan dengan apa yang ditentukan dalam kaidah dan tegasnya, perbuatan yang melanggar larangan yang ditetapkan dalam kaidah hukum dan tidak memenuhi atau melawan perintah yang telah ditetapkan dalam kaidah hukum yang berlaku dalam masyarakat.

Selanjutnya menurut Sue Titus Reid bagi suatu perumusan tentang kejahatan maka yang diperhatiikan adalah : 12

1. Kejahatan adalah suatu tindakan sengaja (omissi). Dalam pengertian ini seseorang dapat dihukum karena pikirannya, melainkan harus ada suatu tindakan atau kealpaan dalam bertindak. Kegagalan untuk bertindak dapat juga merupakan kejahatan. Jika terdapat suatu keajaiban hukum untuk bertindak dalam kasus tertentu, disamping itu ada niat jahat ("criminal insert", "mens rea").

2. Merupakan pelanggaran hukum pidana.

3. Dilakukan tanpa adanya suatu pembelaan atau pembenaran yang diakui secara hukum.

4. Diberi sanksi oleh negara sebagai suatu kejahatan atau pelanggaran.

Berdasarkan beberapa definisi di atas, pada dasarnya kejahatan adalah suatu bentuk perbuatan dan tingkah laku yang melanggar hukum dan

${ }^{11}$ Sudarto, Hukum Pidana I, Yayasan Sudarto, Semarang, 2012.hal 39

${ }^{12}$ Sue Titus Reid, dalam Soerjono Soekanto, Kriminologi Suatu Pengantar Ghalia, Jakarta.Tahun 2013, hal 22

DOI : https://doi.org/10.30598/belovol6issuelpage11-31 
perundangundangan lain serta melanggar norma sosial sehingga masyarakat menentangnya. KUHP tidak memberikan definisi secara tegas tentang pengertian kejahatan. Namun dalam kaitanya dengan kejahatan dapat disimpulkan bahwa semua perbuatan yang disebut dalam buku ke- II Pasal 104 - 488 KUHP adalah kejahatan dan perbuatan lain secara tegas dinyatakan sebagai kejahatan dalam undang-undang di luar KUHP.

Sedangkan Pelanggaran dalam KUHP yang mengatur tentang pelanggaran adalah Pasal 489-569/BAB 1- IX. Pelanggaran adalah “Wetsdelichten” yaitu perbuatanperbuatan yang sifat hukumnya baru dapat diketahui setelah ada wet yang menentukan demikian.

\section{c. Pertanggungjawaban Pidana}

Penegakan hukum dalam penanganan Covid-19 harus dilakukan secara konperhensif dengan tetap melihat kemampuan sesorang melakukan pertangungjawaban pidana. $^{13}$ Pertanggungjawaban terhadap terhadap perbuatan pidana hanya dilakukan oleh sipelaku tindak pidana tersebut berdasarkan asas yang berlaku dalam Hukum Pidana yaitu "Nullu Poena Sine Crimen" (tiada pidana tanpa perbuatan pidana), asas tersebut dapat dapat dipahami bahwa untuk dibebankannya seseorang dengan suatu tanggungjawab hukum harus telah melakukan tindak pidana. ${ }^{14}$ Pertangungjawaban dapat dimintai kepada Orang maupun badan hukum dalam hukum pidana. ${ }^{15}$

Pertanggungjawaban pidana mengandung asas kesalahan (asas culpabilitas), yang didasarkan pada keseimbangan monodualistik bahwa asas kesalahan yang didasarkan pada nilai keadilan harus disejajarkan berpasangan dengan asas legalitas yang didasarkan pada nilai kepastian. Walaupun Konsep berprinsip bahwa pertanggungjawaban pidana berdasarkan kesalahan, namun dalam beberapa hal tidak

\footnotetext{
${ }^{13}$ Erwin Ubwarin, Patrick Corputty. (2020). Pertangungjawaban Pidana Dalam Keadaan Darurat Bencana Covid-19, Mizan: Jurnal Ilmu Hukum, 9(1). 8-15

14 Chairul Bariah, (2017). Perluasan Pertanggungjawaban Terhadap Tindak Pidana Yang Dilakukan Oleh Anak, Syiah Kuala Law Journal : 1(3) 71-93

15 Budi Suhariyanto, (2017). Pertanggungjawaban Pidana Korporasi Berdasarkan Corporate Culture Model dan Implikasinya Bagi Kesejahteraan Masyarakat, Jurnal Recthsvinding, 6(3), 441-448 
menutup kemungkinan adanya pertanggungjawaban pengganti (vicarious liability) dan pertanggungjawaban yang ketat (strict liability). Masalah kesesatan (error) baik kesesatan mengenai keadaannya (error facti) maupun kesesatan mengenai hukumnya sesuai dengan konsep merupakan salah satu alasan pemaaf sehingga pelaku tidak dipidana kecuali kesesatannya itu patut dipersalahkan kepadanya. ${ }^{16}$ Pertanggungjawaban pidana (criminal responsibility) adalah suatu mekanisme untuk menentukan apakah seseorang terdakwa atau tersangka dipertanggungjawabkan atas suatu tindakan pidana yang terjadi atau tidak. Untuk dapat dipidananya si pelaku, disyaratkan bahwa tindak pidana yang dilakukannya itu memenuhi unsur-unsur yang telah ditentukan dalam Undang-undang.

Pertanggungjawaban pidana mengandung makna bahwa setiap orang yang melakukan tindak pidana atau melawan hukum, sebagaimana dirumuskan dalam undang-undang, maka orang tersebut patut mempertanggungjawabkan perbuatan sesuai dengan kesalahannya. Dengan kata lain orang yang melakukan perbuatan pidana akan mempertanggungjawabkan perbuatan tersebut dengan pidana apabila ia mempunyai kesalahan, seseorang mempunyai kesalahan apabila pada waktu melakukan perbuatan dilihat dari segi masyarakat menunjukan pandangan normatif mengenai kesalahan yang telah dilakukan orang tersebut. ${ }^{17}$

Untuk mencegah dilakukannya tindak pidana dengan menegakkan norma hukumdemi pengayoman masyarakat, menyelesaikan konflik yang ditimbulkan tindakpidana, memulihkan keseimbangan, mendatangkan rasa damai dalam masyarakat; memasyarakatkan terpidana dengan mengadakan pembinaan sehingga menjadiorang baik dan membebaskan rasa bersalah pada terpidana, maka Pertanggungjawaban pidana diterapkan dengan menggunakan pemidanaan.Pertanggungjawaban pidana harus memperhatikan bahwa hukum pidana harus digunakan untuk mewujudkan masyarakat adil dan makmur merata materiil dan spirituil. Hukum pidana tersebut digunakan untuk mencegah atau menanggulangi perbuatan yang tidak dikehendaki.

\footnotetext{
${ }^{16}$ Barda Nawawi Arief, Masalah Penegakan Hukum dan Kebijakan Penanggulangan Kejahatan, Bandung: PT. Citra Aditya Bakti,Tahun 2017 hal 23.

${ }^{17}$ Moeljatno, Asas-Asas Hukum Pidana Penerbit Rineka Cipta, Jakarta.Tahun 2015. hal 41.

DOI : https://doi.org/10.30598/belovol6issue1page11-31 
Perbuatan agar dapat dipertanggungjawabkan secara pidana, harus mengandung kesalahan. Kesalahan tersebut terdiri dari dua jenis yaitu kesengajaan (opzet) dan kelalaian (culpa).

1. Kesengajaan (opzet)

Sesuai teori hukum pidana Indonesia, kesengajaan terdiri dari tiga macam, yaitu sebagai berikut: ${ }^{18}$

a. Kesengajaan yang bersifat tujuan

Bahwa dengan kesengajaan yang bersifat tujuan, si pelaku dapat dipertanggungjawabkan dan mudah dapat dimengerti oleh khalayak ramai. Apabila kesengajaan seperti ini ada pada suatu tindak pidana, si pelaku pantas dikenakan hukuman pidana. Karena dengan adanya kesengajaan yang bersifat tujuan ini, berarti si pelaku benar-benar menghendaki mencapai suatu akibat yang menjadi pokok alasan diadakannya ancaman hukuman ini.

b. Kesengajaan secara keinsyafan kepastian

Kesengajaan ini ada apabila si pelaku, dengan perbuatannya tidak bertujuan untuk mencapai akibat yang menjadi dasar dari delik, tetapi ia tahu benar bahwa akibat itu pasti akan mengikuti perbuatan itu.

c. Kesengajaan secara keinsyafan kemungkinan

Kesengajaan ini yang terang-terang tidak disertai bayangan suatu kepastian akan terjadi akibat yang bersangkutan, melainkan hanya dibayangkan suatu kemungkinan belaka akan akibat itu. Selanjutnya mengenai kealpaan karena merupakan bentuk dari kesalahan yang menghasilkan dapat dimintai pertanggungjawaban atas perbuatan seseorang yang dilakukannya.

\section{Kelalaian (culpa)}

Kelalaian (culpa) terletak antara sengaja dan kebetulan, bagaimanapun juga culpa dipandang lebih ringan dibanding dengan sengaja, oleh karena itu delik culpa, culpa itu merupakan delik semu (quasideliet) sehingga diadakan pengurangan pidana. Delik culpa mengandung dua macam, yaitu delik kelalaian yang menimbulkan akibat dan yang tidak menimbulkan akibat, tapi yang diancam

\footnotetext{
${ }^{18}$ Moeljatno, ibid 44
} 
dengan pidana ialah perbuatan ketidak hati-hatian itu sendiri, perbedaan antara keduanya sangat mudah dipahami yaitu kelalaian yang menimbulkan akibat dengan terjadinya akibat itu maka diciptalah delik kelalaian, bagi yang tidak perlu menimbulkan akibat dengan kelalaian itu sendiri sudah diancam dengan pidana. Dengan demikian sesuai dengan uraian di atas maka diketahui bahwa terdapat dua unsur kesalahan sehingga seseorang patut mempertanggungjawabkan perbuatannya di depan hukum, yaitu kesengajaan dan kelalaian.

Berdasarkan uraian di atas maka dapat dinyatakan bahwa pertanggungjawabanpidana mengandung makna bahwa setiap orang yang melakukan tindak pidanaatau melawan hukum, sebagaimana dirumuskan dalam undang-undang, makaorang tersebut patut mempertanggungjawabkan perbuatan sesuai dengankesalahannya. Orang yang melakukan perbuatan pidana akanmempertanggungjawabkan perbuatan tersebut dengan pidana apabila iamempunyai kesalahan, seseorang mempunyai kesalahan apabila pada waktumelakukan perbuatan dilihat dari segi masyarakat menunjukan pandangannormatif mengenai kesalahan yang telah dilakukan orang tersebut.

Hal yang mendasari pertangungjawaban tindak pidana adalah pemahaman bahwasetiap manusia dianugerahi Tuhan Yang Maha Esa dengan akal budi dan nuraniyang memberikan kepadanya kemampuan untuk membedakan yang baik dan yangburuk yang akan membimbing dan mengarahkan sikap dan perilaku dalammenjalani kehidupannya. Dengan akal budi dan nuraninya itu, maka manusiamemiliki kebebasan untuk memutuskan sendiri perilaku atau perbuatannya. Selain untuk mengimbangi kebebasan, manusia memiliki kemampuan untuk bertanggungawab atas semua tindakan yang dilakukannya.

\section{d. Bentuk Pertanggunjawaban Pidana Dalam Pengambilan Jenasah Covid-19 Secara Paksa Berdasarkan Aturan Tindak Pidana Umum dan Aturan Pidana Khusus}


Kebiajakan-kebiakan hukum pidana harus dilakukan secara terpadu dalam penegakan hukum. ${ }^{19}$ Pengambilan paksa jenasa pasien Covid-19 oleh pihak-pihak yang tidak mempunyai kewenagan adalah merupakan tindakan melawan hukum. Hal ini bertentangan dengan prosedur penangan jenasa Covid-19 Menurut sistem KUHP Indonesia, yang dapat menjadi subjek hukum pidana ialah natuurlijke person atau manusia. Hal itu dapat dilihat dalam tiap-tiap pasal dalam KUHP Buku II dan Buku III. Sebagian besar kaidah-kaidah hukum pidana diawali dengan kata barangsiapa sebagai kata terjemahan dari kata Belanda hij.

Kenyataanya pengambilan paksa jenazah virus corona atau Covid-19 dinilai berbahaya. Disebabkan penyakit yang tengah dihadapi oleh seluruh dunia ini merupakan penyakit yang mudah menular. Praktik ternyata sering terjadi pengambilan secara paksa jenasah pasien Covid-19. Para pelaku adalah mereka yang melakukan tindakan tersebut, biasanya lebih dari seorang terlibat dalam peristiwa pengambilan jesanah itu. Para pelaku tersbut terdiri seorang atau beberapa orang lain yang turut serta. Bahwa penyertaan sebagaimana dalamBuku I KUHP berarti turut sertanya seorang atau lebih pada waktu seorang lain melakukan suatu tindak pidana. Rumusan ini terlihat pada Pasal 55 dan Pasal 56 KUHP. Oleh kedua pasal ini diadakan lima golongan peserta tindak pidana yaitu :

1. yang melakukan perbuatan (plegen, dader),

2. yang menyuruh melakukan perbuatan (doen plegen, middelijke dader),

3. yang turut melakukan perbuatan (medeplegen, mededader),

4. yang membujuk supaya perbuatan dilakukan (uitlokken, uitlokker),

5. yang membantu perbuatan (medeplichtig zijn, medeplichtige).

Ajaran Penyertaan dalam Tindak Pidana erat kaitannya dengan perbuatan dan pertanggungjawaban pidana, konsep dasar pertanggungjawaban pidana merupakan konsep sebuah perbuatan pidana. Jadi Ajaran Penyertaan Pidana dan Pertanggungjawaba Pidana dalam hukum selalu berpangkal tolak dari Ajaran

${ }^{19}$ Leonie Lokollo, Yonna Beatrix Salamor, Erwin Ubwarin. (2020). Kebijakan Formulasi Undang-undang Narkotika Dalam Legalisasi Penggunaan Ganja Sebagai Bahan Pengobatan di Indonesia. Jurnal Belo, 5 (2). Hal 1-10 
Penyertaan Pidana dan Perbuatan Pidana dengan dimensi peran dalam penyertaan perbuatan pidana dalam suatu tindak pidana.

Implementasi hukum pidana terhadap para pelaku pengambilan paksa jenasah pasien Covid-19 berkaitan dengan pertanggunggjawaban pelaku berarti mengenakan sifat tercela dari perbuatan pidana pada orang itu sesuai dengan peran dan kapasitas pelaku atau kontribusinya dalam mewujudkan tindak pidana, sehingga patut dijatuhkan nestapa kepadanya. Jadi, tolok ukur atau penentuan mengenai cakupan pertanggungjawaban pidana sangat tergantung terhadap rumusan dan ruang lingkup perbuatan pidana yang ditentukan sebelumnya serta konsep Ajaran Penyertaan di dalam hukum pidana positif.

Dalam hal pengambilan paksa terhadap jenasah pasien Covid-19 para penegak hukum menjerat para pelaku dengan KUHP sebagai tindak pidana umum : Pasal 214, 335 KUHP, 336 KUHP;

Pasal 214 ayat (1) : Paksaan dan perlawanan berdasarkan pasal 211 dan 212 jika dilakukan oleh dua orang atau lehih dengan bersekutu, diancam dengan pidana penjara paling lama tujuh tahun

Pasal 211

: Barang siapa dengan kekerasan atau ancaman kekerasan memaksa seorang pejabat untuk melakukan perbuatan jabatan atau untuk tidak melakukan perbuatan jabatan yang sah, diancam dengan pidana penjara paling lama empat tahun.

Pasal 212 Barang siapa dengan kekerasan atau ancaman kekerasan melawan seorang pejabat yang sedang menjalankan tugas yang sah, atau orang yang menurut kewajiban undang-undang atau atas permintaan pejabat memberi pertolongan kepadanya, diancam karena melawan pejabat, dengan pidana penjara paling lama satu tahun empat bulan atau 
pidana denda paling banyak empat ribu lima ratus rupiah.

Pasal 335 ayat (1) : Diancam dengan pidana penjara paling lama satu tahun atau denda paling banyak empat ribu lima ratus rupiah:

1. barang siapa secara melawan hukum memaksa orang lain supaya melakukan, tidak melakukan atau membiarkan sesuatu, dengan memakai kekerasan, sesuatu perbuatan lain maupun perlakuan yang tak menyenangkan, atau dengan memakai ancaman kekerasan, sesuatu perbuatan lain maupun perlakuan yang tak menyenangkan, baik terhadap orang itu sendiri maupun orang lain;

Pasal 336 ayat (1) Diancam dengan pidana penjara paling lama dua tahun delapan bulan, barang siapa mengancam dengan kekerasan terhadap orang atau barang secara terang-terangan dengan tenaga bersama, dengan suatu kejahatan yang menimbulkan bahaya umum bagi keamanan orang atau barang, dengan perkosaan $\mathrm{K}$ atau perbuatan yang melanggar kehormatan kesusilaan, dengan sesuatu kejahatan terhadap nyawa, dengan penganiayaan berat atau dengan pembakaran.

Kemudian berkaitan dengan masalah virus Covid-19 yang merukan wabah penyakit secara khusustelah diatur dalam Undang-undang No. 4 Tahun 1984 tentang Wabah Penyakit Menular (UU Wabah Penyakit Menular). Demikian pula adanya Undang-undang No. 6 Tahun 2018 tentang Karantina Kesehatan, yang 
secara implisit mengatur mengenai wabah penyakit, khususnya merujuk pada Pasal 93 UU Karantina Kesehatan. :

Pasal 93: $\quad$ Setiap orang yang tidak mematuhi penyelenggaraan
Kekarantinaan Kesehatan sebagaimana dimaksud dalam
Pasal 9 ayat (1) dan/atau menghalang-halangi
penyelenggaraan Kekarantinaan Kesehatan sehingga
menyebabkan Kedaruratan Kesehatan Masyarakat
dipidana dengan pidana penjara paling lama 1 (satu)
tahun dan/atau pidana denda paling banyak Rp
100.000.000,00 (seratus juta rupiah).

Sadangkan Pasal 14 Undang-undang No. 4 Tahun 1984 tentang Wabah Penyakit Menular disebutkan:

(1) Barang siapa dengan sengaja menghalangi pelaksanaan penanggulangan wabah sebagaimana diatur dalam Undang-Undang ini, diancam dengan pidana penjara selama-lamanya 1 (satu) tahun dan/atau denda setinggi-tingginya $\mathrm{Rp}$ 1.000.000,- (satu juta rupiah).

Bahwa sesuai dengan upaya penanggulangan yang termuat dalam Pasal 5 :

(1) Upaya penanggulangan wabah meliputi:

a. penyelidikan epidemiologis;

b. pemeriksaan, pengobatan, perawatan, dan isolasi penderita, termasuk tindakan karantina;

c. pencegahan dan pengebalan;

d. pemusnahan penyebab penyakit;

e. penanganan jenazah akibat wabah;

f. penyuluhan kepada masyarakat;

g. upaya penanggulangan lainnya.

(2) Upaya penanggulangan wabah sebagaimana dimaksud dalam ayat (1) dilaksanakan dengan memperhatikan kelestarian lingkungan hidup. 
Ayat 2 di kemudian diakomodir dengan memberikan tempat khusus atau makam khusus bagi mereka yang meninggal disebabkan oleh virus tersebut.

Selanjutnya rumuskan Pasal 55 KUH sudah memadai dalam pemberantasan tindak pidana umum maupun tindak pidana khusus dengan peran dan struktur pelaku yang kompleks. Bentuk-bentuk yang dimaksudkan di dalam Pasa1 55 KUHP sebagai berikut:

a) Pelaku pelaksana disebut plegen

Istilah plegen yakni mereka yang melakukanperbuatan pidana. Dalam memorie van toelichting tidak dijumpaiketerangan sedikitpun, padahal plegendiketahui bagian atau termasuk juga dader.Halini menjadi tidak sukar menentukan siapa yangdisebut sebagai plegen atau pelaku pidanamanakala rumusan delik berasal dari Bukukedua dan ketiga, tetapi sebaliknya memerlukananalisis terlebih dulu untuk menentukan plegenyang dirumuskan di luar dari Undang-UndangTindak Pidana Di luar KUH Pidana.

b) Pelaku sebagai penyuruh disebut doenplegen

Pelaku sebagai penyuruh perbuatan pidanaadalah bentuk kedua dari penyertaan yangterdapat di dalam Pasal 55 KUH Pidana. Dalampasal tersebut tidak diterangkan apa yangdimaksud dengan penyuruh itu, tetapi dalammemorie van toelictingdijelaskan sebagai berikut:

"Penyuruh perbuatan pidana (doen plegen) adalah juga dia yang melakukan perbuatanpidana tetapi tidak secara pribadi, melainkandengan perantaraan orang lain, sebagai alatdalam tangannya, apabila orang lain ituberbuat tanpa kesengajaan, kealpaan atautanggungjawab karena keadaan yang tahu,disesatkan atau tunduk pada kekerasan:

c) Pelaku Peserta disebut medeplegen

Bentuk ketiga dari penyertaan perbuatanpidana (deelneming) adalah medeplegen yakni bentuk perbuatan pidana yang berada di antara pelaku pelaksana (plegen) dengan pembantuan (medeplichtig). Pelaku peserta adalah orang yang turut serta melakukan sebagian dari unsur-unsur delik. Jadi bedanya antara pelaku peserta dengan pelaku pembantu perbuatan pidana adalah: "Pelaku pelaksanan (plegen) sebagai pembuat pidana tunggal DOI : https://doi.org/10.30598/belovol6issue1page11-31 
yaitumelaksanakan semua unsur-unsur delik, sedangkan pelaku peserta hanya melaksanakan sebagian saja dari unsur-unsur delik danbersama dengan temannya menyelesaikan delik itu:"

d) Pembujuk atau penganjur uitlokken

Bentuk keempat dari penyertaan diaturdalam Pasal 55 ayat (1) sub ke-2 dan ayat (2) KUH Pidana, sebagaimana dengan doen plegen bahwa uitlokken juga merupakan auctorintelectualis, tetapi sebagaimana penyuruhperbuatan pidana bahwa penganjur ataupembujuk perbuatan pidana tidak melaksanakan sendiri unsur-unsur delik, melainkan dilaksanakan oleh orang lain dan perbuatan tersebut dilakukan oleh orang lainkarena atau disebabkan anjuran atau bujukan dari penganjur tersebut.

Pertanggungjawaban pidana seorangpenganjur atau pembujuk menurut $\operatorname{Vos}^{20}$ harus memenuhi persyaratan :

1. kesengajaandan penganjuran atau pembujukan ditujukanterhadap dilaksanakannya suatu delik;

2. upaya-upaya yang disebut dalamundang-undang dan berusaha agar si pelaksana perbuatan pidana melaksanakan delik tersebut;

3. si pelaksana perbuatan pidana tergerakhatinya oleh upaya tersebut;

4. dengandilaksanakannya delik tersebut atau paling tidakpercobaan melakukan delik, si pelaksanaperbuatan pidana dapat dipidana asalkan atauharus sesuai dengan keinginan pengajur ataupembujuk.

e) Pembantuan (Medeplechtige)

Pada dasarnya pembantuan adalah bentuk ke-5 dari penyertaan yang diatur di dalam Pasal 56, 57 dan 60 KUHP. Definisi pemberian bantuan sebelum dan ketika delik terlaksana pada hakekatnya adalah perbuatan yang tidak termasuk perbuatan pelaksanaan dari suatu delik, melainkan merupakan perbuatan "yang mempermudah" terjadinya suatu delik atau memperlancar terlaksananya suatu delik. Argumentasi bahwa pembantuan merupakan bentuk kelima dari

${ }^{20}$ Muladi dan Dwidja Priyatno, PertanggungjawabanKorporasi Dalam Hukum Pidana, Bandung: Sekolah Tinggi Bandung, Tahun. 2015. hal 106

DOI : https://doi.org/10.30598/belovol6issue1page11-31 
penyertaan menurut hukumpidana Indonesia adalah sebagaimana hukumpidana Belanda yang dikutip dalam KUHP bahwa title V tentang Deelneming aan strafbarefeiten termasuk pula pembantuan di mana khusus bentuk kesatu sampai kelima diaturdalam Pasal 47 dan pembantuan diatur dalamPasal 48 Wetboek van Strafrecht atau Pasal 55dan 56 KUHP.

Kebijakan meminta pertangungjawaban pidana harus melihat apa peran pelaku dalam tindak pidana, ${ }^{21}$ untuk itu meminta pertanggungjawaban pidana kepada pembuat delik atau pidana dibagi menjadi 2 (dua) yakni pertama, penanggungjawab penuh dan kedua, penanggungjawab sebagian. Penangungjawab penuh sanksi pidana adalah mereka yang tergolong dader sebagai penanggungjawab mandiri; mededader sebagai penanggungjawab bersama; medeplegen sebagai penanggungjawab serta; doen plegen sebagai penanggungjawab penyuruh; dan uitlokken sebagai penanggungjawab pembujuk atau perencana. Sedangkan penanggungjawab sebagian adalah mereka yang tergolong sebagai poger sebagai penanggungjawab percobaan perbuatan pidana dan medeplichtige sebagaipenanggungjawab pemberi bantuan dalam melakukan perbuatan pidana.

Secara doktrinal pertanggungjawaban pidana dalam ajaran penyertaan pidana terdapat 2 (dua) paham yakni pertama, sebagai bentukpenyertaan yang berdiri sendiri disebut zelfstandige vormen van deelneming yakni pertanggungjawaban pidana terletak pada setiap peserta yang dihargai sendiri-sendiri dankedua, bentuk kesertaan yang tidak berdiri sendiri disebut onzelfstand ige vormen vandeelnemingatau accesoire van deelnemingyakni pertanggungjawaban pidana peserta bergantung kepada peserta pidana lainnya. ${ }^{22}$

\section{Penutup}

Kesimpulan

Adapun bentuk pertanggunjawaban pidana dalam pengambilan jenasah Covid19 secera paksa berdasarkan Aturan tindak pidana umum dan aturan tindak pidana

21 Eprina Mawati, (2020). Kebijakan Hukum Pidana Mengenai Rehabilitasi Psikososial Korban Tindak Pidana Terorisme Dalam Sistem Peradilan Pidana, Jurnal Bel. 5 (2). Hal 34-56

${ }^{22}$ Tommy J. Bassang, (2015) Pertanggungjawaban Pelaku Tindak Pidana Deelneming, LexCrimen Vol. IV/No. 5/Juli hal 102 
Khusus. Pertanggungjawaban pidana harus diberikan kepada meraka yang tergolong dader sebagai penanggungjawab mandiri; mededader sebagai penanggungjawab bersama; medeplegen sebagai penanggungjawab serta; doen plegen sebagai penanggungjawab penyuruh; dan uitlokken sebagai penanggungjawab pembujuk atau perencana. Sedangkan medeplichtige sebagai penanggungjawab pemberi bantuan dalam melakukan perbuatan pidana.

Saran

Dalam pengambilan jenasah pasien Covid-19 melibatkan lebih dari satu pelaku, penegak hukum harus memperhatikan ajaran penyertaan dalam melakukan penyidikan sebagai dasar memperluas dapat dipidananya orang yang tersangkut dalam terwujudnya delik. Dalam suatu perkara pidana adalah sangat penting menemukan hubungan antar pelaku dalam menyelesaikan suatu tindak pidana, yakni bersama-sama melakukan tindak pidana, seorang mempunyai kehendak dan merencanakan kejahatan sedangkan menggunakan orang lain untuk melaksanakan tindak pidana tersebut.

\section{Daftar Pustaka}

\section{Jurnal}

[1] Anakotta, M. Y. (2020). Kebijakan Sistem Penegakan Hukum Terhadap Penanggulangan Tindak Pidana Terorisme Melalui Pendekatan Integral, Jurnal Belo 5(1), 46-66 DOI : https://doi.org/10.30598/belovol5issuelpage46-66

[2] Bariah, C. (2017). Perluasan Pertanggungjawaban Terhadap Tindak Pidana Yang Dilakukan Oleh Anak, Syiah Kuala Law Journal : 1(3) 71-93 DOI : https://doi.org/10.24815/sklj.v1i3.9640

[3] Bassang, T. J. (2015) Pertanggungjawaban Pelaku Tindak Pidana Deelneming, LexCrimen Vol. IV/No. 5/Juli. 102 
[4] Leonie Lokollo, Yonna Beatrix Salamor, Erwin Ubwarin. (2020). Kebijakan Formulasi Undang-undang Narkotika Dalam Legalisasi Penggunaan Ganja Sebagai Bahan Pengobatan di Indonesia. Jurnal Belo, 5 (2). 1-10 DOI : https://doi.org/10.30598/belovol5issue2page1-20

[5] Mawati, E., Takariawan, A., \& Sulistiani, L. (2020). Kebijakan Hukum Pidana Mengenai Rehabilitasi Psikososial Korban Tindak Pidana Terorisme Dalam Sistem Peradilan Pidana. Jurnal Belo, Volume 5, Nomor 2, 34-56. DOI : https://doi.org/10.30598/belovo15issue2page34-56

[6] Paramita Sari, A. (2017). Pertanggungjawaban Pidana dan Pemidanaan Terhadap Pelaku Pedofilia Dalam Hukum Pidana Indonesia. Jurnal Magister Hukum Udayana (Udayana Master Law Journal), 6(1), 23 - 36. DOI : https://doi.org/10.24843/JMHU.2017.v06.i01.p03

[7] Suhariyanto. B. (2017). Pertanggungjawaban Pidana Korporasi Berdasarkan Corporate Culture Model dan Implikasinya Bagi Kesejahteraan Masyarakat, Jurnal Recthsvinding, 6(3), 441-448

[8] Ubwarin, E., \& Corputty, P. (2020). Pertangungjawaban Pidana Dalam Keadaan Darurat Bencana Covid-19. Mizan: Jurnal Ilmu Hukum, Volume 9 Nomor 1. Hal 6. DOI : https://doi.org/10.32503/mizan.v9i1.1043

\section{Buku}

[9] Arief B. N. (2017). Masalah Penegakan Hukum dan Kebijakan Penanggulangan Kejahatan, Bandung: PT. Citra Aditya Bakti.

[10] Chazawi, A. (2007), Pelajaran Hukum Pidana II, Jakarta: Raja Grafindo Persada.

[11] Kansil C.S.T. \& Kansil C. S.T, (2014), Pokok-Pokok Hukum Pidana, Jakarta: Pradnya Paramita

[12] Lamintang P.A.F., (2014), Dasar-dasar Hukum Pidana Indonesia, Sinar Baru,Bandung.

[13] Moeljatno, (2015). Asas-Asas Hukum Pidana Penerbit Rineka Cipta, Jakarta. 
[14] Muladi dan Priyatno. D, (2015). PertanggungjawabanKorporasi Dalam Hukum Pidana, Bandung: Sekolah Tinggi Bandung

[15] Roeslan Saleh, (2011), "Perbuatan Pidana dan Pertanggungjawaban Pidana, Dua Pengertian Dasar dalam Hukum Pidana”, Jakarta : Centra..

[16] Sudarto, (2012), Hukum Pidana I, Semarang: Yayasan Sudarto.

[17] Sue Titus Reid, dalam Soerjono Soekanto, (2013), Kriminologi Suatu Pengantar, Jakarta : Ghalia

\section{Lain-lain}

[18] https://bebas.kompas.id/baca/riset/2020/04/18/rangkaian-peristiwa-pertamacovid-19/. diakses 17 Juli 2020

[19] https://www.kompas.com/sains/read/2020/05/11/130600623/diumumkan-awalmaret-ahli--virus-corona-masuk-indonesia-dari-januari. diakses 17 Juli 2020

[20] https://www.kompas.com/sains/read/2020/05/11/130600623/diumumkan-awalmaret-ahli--virus-corona-masuk-indonesia-dari-januari. diakses 17 Juli 2020 